\title{
EXPLAINING INDIVIDUAL- AND COUNTRY-LEVEL VARIATIONS IN UNREGISTERED EMPLOYMENT USING A MULTI-LEVEL MODEL: EVIDENCE FROM 35 EURASIAN COUNTRIES
}

Besnik A. Krasniqi, Colin C. Williams

\section{Abstract}

The aim of this paper is to evaluate the individual- and country-level variations in unregistered employment. To analyse whether it is marginalised groups who are more likely to engage in unregistered employment and explain the country-level variations, a 2010 Life in Transition Survey (LiTS) involving 38,864 interviews in 35 Eurasian countries is reported. Multilevel logistic regression analysis reveals that younger age groups, the divorced, and those with fewer years in education, are more likely to be unregistered employed. On a country-level, meanwhile, the prevalence of unregistered employment is strongly associated with tax morale; the greater the asymmetry between informal and formal institutions, the greater is the prevalence of unregistered employment. It is also higher when GDP per capita as well as social distribution and state intervention (subsidies and transfers, social contribution expenditure, health expenditure) are lower. The paper concludes by discussing the theoretical and policy implications.

Keywords: informal sector; tax morale, institutional theory; labour law; tax evasion; Europe.

JEL classification: $\mathrm{H} 26, \mathrm{~J} 46, \mathrm{~K} 34, \mathrm{~K} 42, \mathrm{O} 17, \mathrm{P} 2$

\section{INTRODUCTION}

Tackling unregistered employment is high on the political agenda both in Europe and beyond. This is exemplified by the European Commission establishing the European Platform Tackling Undeclared Work (European Commission 2016) and the International Labour Organisation passing Recommendation 208 (ILO 2015). The reason it is high on the political agenda is because the prevalence of employees without written contracts or terms of employment means not only that the state has reduced control over the quality of working conditions, but it also weakens trade union and collective bargaining, and it increases pressure on legitimate businesses to themselves employ unregistered workers due to the unfair competition they witness (Andrews, Sanchez, and Johansson 2011)

2011; Williams 2014). To advance understanding of this phenomenon, the aim of this paper is to evaluate the individual- and country-level variations in unregistered employment so as to provide a new way of explaining and tackling this employment relationship.

To do so, this paper draws upon theoretical developments in the study of the wider informal economy in order to evaluate the individual- and countrylevel variations in unregistered employment. On the hand, this paper evaluates at the individual-level the

Besnik A. Krasniqi, PhD

Associate Professor of Entrepreneurship and

Small Business

University of Prishtina «Hasan Prishtina»

E-mail: besnik.krasniqi@uni-pr.edu

Colin C. Williams, PhD

Professor of Public Policy

Sheffield University Management School (SUMS)

University of Sheffield

E-mail: C.C.Williams@sheffield.ac.uk 
marginalisation thesis which asserts that populations marginalised from the formal labour market are more likely to engage in unregistered employment (see Williams and Horodnic 2015a,b,c). On the other hand, and to explain country-level variations, this paper follows the lead of recent developments in the study of the informal economy by drawing inspiration from institutional theory (Baumol and Blinder 2008; Helmke and Levitsky 2004; North 1990). This argues that all societies have formal institutions (i.e., codified laws and regulations) that define the legal rules of the game and informal institutions which are socially shared unwritten rules (Helmke and Levitsky 2004). When there is asymmetry between these formal and informal institutions, the result is the emergence of forms of work such as unregistered employment. If correct, then it suggests that reducing the commonality of this practice will require not simply the stronger enforcement of formal rules (e.g., by using effective workplace inspections), but also a new emphasis on the reduction of this institutional asymmetry, which will require changes in both informal and formal institutions. To determine the changes in formal institutions required, three theories are evaluated which have sought to explain the various country-level formal structural imperfections and failings that are argued to result in larger informal economies (Krasniqi, 2007; Krasniqi 2011; Williams 2013; Krasniqi and Mustafa 2016; Lajqi and Krasniqi 2017), namely: economic under-development and the lack of modernisation of government (modernisation thesis); too much state interference in social expenditure and redistribution (state overinterference thesis), or inadequate state intervention and protection of workers (state under-intervention thesis). Here, however, these structural conditions are more seen as ways of reducing institutional asymmetry rather than free-standing explanations.

Therefore, this paper makes following important contributions to the informal economy literature. Firstly, in the paper reveals some support for the marginalisation thesis in relation to unregistered employment, although it reveals that care is required when identifying which marginal groups are more likely to engage in unregistered employment. Secondly, by revealing the strong association between tax morale and participation in unregistered employment, it confirms the usefulness of an institutional theory framework. Thirdly, and importantly for advancing understanding of unregistered employment from an institutional theory viewpoint, the finding of this multilevel analysis (individuals within countries) is that the propensity to engage in unregistered employment is higher when the level of economic development is lower (confirming modernisation theory) and when the levels of social distribution and state intervention (subsidies and transfers, social contribution expenditure, health expenditure) are lower (confirming state under-intervention theory and refuting state overinterference theory). Finally, the paper contributes to literature by testing the hypothesis in a cross-country analysis in a sample of countries with varying degree of insertional reforms, thus making our findings stronger in terms of heterogeneity of sample.

The paper is structured as follows. To advance understanding on unregistered employment, section 2 briefly reviews the previous literature on unregistered employment and draws upon the study of the wider informal economy to develop hypotheses regarding the individual- and country-level variations. To test these hypotheses, section 3 then reports the data used, namely the 2010 Life in Transition Survey (LiTS) involving 38,864 interviews in 35 Eurasian countries, and the analytical methods employed; a multi-level logistic regression model utilizing the hierarchical nature of the data (individuals within countries). Section 4 reports the findings regarding the individual- and country-level variations in unregistered employment, while section 5 draws conclusions about the theoretical and policy implications of the findings.

\section{EXPLAINING UNREGISTERED EMPLOYMENT: THEORETICAL FRAMING AND HYPOTHESES DEVELOPMENT}

The informal economy, by which is here meant paid work that is not unregistered by, or not declared to, the authorities for tax, social security and/or labour purposes (Khan 2017; Slack et al. 2017; Williams 2017; Williams and Windebank 1998; Windebank and Horodnic 2017), has attracted the interest of both policymakers and academics in recent years. This stems from that fact that globally, 60 per cent of jobs globally are in the informal economy (Jütting and Laiglesia 2009) and that the informal economy is expanding relative to the formal economy in many global regions (ILO 2011; Williams 2014; Williams and Schneider 2016).

The informal economy includes not only paid work without a legal written contract (i.e., unregistered employment) but also other paid work not declared to the authorities. This includes formal employers not declaring some and/or all of the work they undertake and also under-declaring employment by paying some and/or all formal employees an official declared wage and an additional undeclared (envelope) wage (ILO 2015; Williams 2017b). Although the informal economy as whole has been subject to widespread 
evaluation in recent years, unregistered employment has received little attention. The only exceptions are Hazans (2011) and Williams and Kayaoglu (2017), both of which evaluate its prevalence. Williams and Kayaoglu (2017) find that in the European Union, 5 per cent of employees reported that they did not have a written contract of employment in 2013, while Hazans (2011), using European Social Survey data on 30 countries for the period between 2004 and 2009, finds that the proportion of employees without a contract is $2.7 \%$ in Nordic countries, 9.5\% in Southern Europe, and 5 per cent in Western and East-Central Europe.

The result is that not only are there few, if any, studies of the individual-level distribution of unregistered employment, but neither has there been any attempt to explain the country-level variations. To do so, therefore, theories used to explain the individualand country-level variations in the broader informal economy can be used (Williams 2014; Williams and Horodnic 2016).

When theorising the informal economy at the individual level, a marginalisation thesis dominates, which argues that the informal economy is concentrated among populations marginalised from the formal labour market and social protection (Williams and Horodnic 2015a,b, c, 2017a). Until now, some limited evidence exists to support this marginalization thesis when studying the informal economy. Studies have shown informal employment to be concentrated among those more likely to be excluded from the formal labour market, including the unemployed (Brill 2011; Slavnic 2010; Taiwo 2013) and women (ILO 2013; Leonard 1994; Stănculescu 2004). However, other studies reveal that the unemployed are not more likely to participate (Williams 2001), and that men are more likely to participate (Lemieux, Fortin, and Frechette 1994; Mclnnis-Dittrich 1995). Indeed, a recent evaluation of this marginalisation thesis in relation to the informal economy across the European Union reveals that although valid when discussing younger people, it is not when considering those with fewer years in education, women and the unemployed (Williams and Horodnic 2015b). Meanwhile, and in relation to underdeclared employment (i.e., where formal employees are paid an official declared wage and an additional undeclared 'envelope' wage so that employers evade paying their full tax and social contributions), the finding has been that this is more likely among younger persons, men, divorced people (doubtless to hide their level of income), and unskilled manual workers (Williams and Horodnic 2017b), suggesting again that some marginal populations are more likely to be engaged in the informal economy but not others.

The only known studies of the distribution of unregistered employment similarly find partial support for the marginalisation thesis. Although Williams and Kayaoglu (2017) find no significant association between various socio-demographic and socio-economic factors (i.e., gender, age, educational level, and occupational status) and the probability of unregistered employment, Hazans (2011) finds that the likelihood of unregistered employment is inversely related to education level, students more likely than other occupational groups, older and younger employees more likely, and women more likely than men to work without a contract. Based on these findings from the study of the informal economy in general, and the only two studies of unregistered employment, regarding the relevance of the marginalisation thesis when explaining its distribution, we can therefore here test the following propositions:

Individual-level marginalisation hypothesis $(\mathrm{H} 1)$

$\mathrm{H} 1 \mathrm{a}$ : Women are more likely to participate in unregistered employment than men.

$\mathrm{H} 1 \mathrm{~b}$ : Younger age groups are more likely to participate in unregistered employment than older age groups.

H1c: Those divorced or separated are more likely to participate in unregistered employment than married individuals.

H1d: Those with fewer years in formal education are more likely to participate in unregistered employment than those who spent longer in formal education.

H1e: Homeowners are less likely to participate in unregistered employment than those renting or paying a mortgage.

Turning to country-level variations, it is again the case that theories of the wider informal economy can be used to explain cross-national variations in the prevalence of unregistered employment. In recent years, a new umbrella theorisation, drawing inspiration from institutional theory (Baumol and Blinder 2008; North 1990), has emerged to explain individualand country-level variations in the informal economy (Williams and Horodnic 2015a,b,c). This could be also used to explain unregistered employment. From this institutionalist perspective, all societies have formal institutions, which are codified laws and regulations that define the legal rules of the game, and informal institutions, which are the 'socially shared rules, usually unwritten, that are created, communicated and enforced outside of officially sanctioned channels' (Helmke and Levitsky 2004: 727). According to the institutional theory research, asymmetries between formal and informal institutions can have negative 
impact on economic development (Williams and Vorley 2015; Krasniqi 2014). Literature argues that formal and informal institutions interact in two key ways, with formal institutions either supporting (i.e. complementing) or undermining (i.e. substituting) informal institutions (Williams et al. 2017; Tonoyan, Strohmeyer, and Habib 2010; Krasniqi and Desai 2016; Hashi and Krasniqi 2011). Informal institutions can complement formal institutions if they create incentives to comply with the formal institutions, thereby addressing problems of social interaction and coordination and enhancing the efficiency of formal institutions (Baumol 1990; North 1990). Similarly, labour law violations, such as engaging in unregistered employment thus arise when there is a gap between the formal institutions and informal institutions. When this gap is large, the prevalence of unregistered employment will be higher (cf. Kistruck et al. 2015; Webb et al. 2009). The greater the degree of asymmetry between formal and informal institutions, the more prevalent will be unregistered employment (cf. Williams and Horodnic 2015a,b). Here, therefore, and to test this explanation for country-level variations, the following proposition can be tested:

Institutional asymmetry hypothesis $(\mathrm{H} 2)$ : The greater is the asymmetry between formal and informal institutions, the greater is the prevalence of unregistered employment.

What, however, causes the existence of this asymmetry? Much of the existing literature asserts that it is country-level formal institutional imperfections and failures that lead populations' norms, values and beliefs not to be in symmetry with the codified laws and regulations. In the study of the informal economy, three alternative theories exist that seek to explain the country-level formal structural imperfections and failings that result in larger informal economies (Williams 2013).

Firstly, a 'modernisation' thesis has argued that the informal economy becomes less prevalent with economic development and the modernisation of government which leads to a reduction in public sector corruption (Lewis 1959; Packard 2007). Applying this to the cross-national variations in unregistered employment, this perspective would thus view unregistered employment as more prevalent in less developed economies, measured in terms of GDP per capita, and societies in which there is a lack of modernisation of the state bureaucracy. To explore its validity, therefore, the following hypothesis can be tested:

Modernisation hypothesis (H3): Unregistered employment will be less prevalent in wealthier and more modernised economies.

H3a: Unregistered employment will be less prevalent in wealthier economies

H3b: Unregistered employment will be less prevalent in societies with stronger legal rights.

H3c: Unregistered employment will be less prevalent in societies with lower levels of corruption.

Secondly, a 'state over-interference' thesis asserts that the informal economy is the result of high taxes and too much state interference in the free market and that reducing taxes and state interference in work and welfare arrangements is the way forward (De Soto 1989, 2001; London and Hart 2004; Nwabuzor 2005; Schneider and Williams 2013). From this perspective therefore, unregistered employment will be more prevalent in countries with higher taxes and levels of state interference in work and welfare systems. To explore the validity of this explanation in consequence, the following hypothesis can be tested:

State over-interference hypothesis $(\mathrm{H} 4)$ : unregistered employment will be less prevalent in economies with lower levels of state-interference.

Third and finally, and inverse to the 'state overinterference' thesis, a 'state under-intervention' thesis claims that the informal economy results from inadequate levels of state intervention in work and welfare arrangements which leaves workers less than fully protected. The focus therefore should be upon introducing social protection for workers, reducing inequality and pursuing labour market interventions to help vulnerable groups (Castells and Portes 1989; Davis 2006; Gallin 2001; ILO 2014; Slavnic 2010; Taiwo 2013). In consequence, unregistered employment from this perspective will be less prevalent in countries with relatively high levels of state intervention in work and welfare arrangements. To evaluate the validity of this explanation therefore, the following hypothesis can be tested:

State under-intervention hypothesis (H5): Unregistered employment will be less prevalent in economies with greater state intervention

\section{DATA AND VARIABLES}

\subsection{Data and sample}

To evaluate these hypotheses in relation to Eurasian countries, data is here reported from the second round of the Life in Transition Survey (LiTS II), conducted 
jointly by the World Bank and the European Bank for Reconstruction and Development (EBRD) in 2010 (for details see EBRD 2011; Williams and Krasniqi 2017). The survey covers 35 Eurasian countries with varying degrees of economic development, including transition and developed economies ${ }^{1}$. The survey coverage has been expanded to include five western European "comparator" countries (France, Germany, Italy, Sweden and the UK) 'allowing us to benchmark the transition region against some advanced market economies, thereby giving a clearer perspective on the remaining challenges facing transition countries' (EBRD 2011, p.2).

In each country, a nationally representative sample of between 1000-1500 households was selected for face-to-face interviews, depending on the size of the country. The advantage of the LiTS is that it builds on a consistent sampling methodology across countries. Within each household the head of household was interviewed about individual and household characteristics, and the 'last birthday' rule was applied to randomly choose the household member (who could also be the household head) for the remaining modules of the survey. The standard approach to sample design in each country was multi-stage random probability stratified clustered sampling. The sample was stratified by geographical region and the level of urbanity. To aid the development of the questionnaire, two rounds of piloting were conducted.

The questionnaire enables a detailed analysis of how people across the region perceive the impacts of transition on their lives and their attitudes towards transition issues in general. The survey contains specific questions on peoples' economic status and for those employed, whether they have written work contracts or not. The survey also contains information about their attitudes towards paying taxes as well as their individual (gender, age, marital status, education) and household characteristics (owning or renting a house). In addition to the results of this survey, the original database has been here combined with country-level indicators from the World Bank such as GDP per capita, government spending, health expenditures, corruption perception index, and strength of the legal rights system. The country level indicators enable an evaluation of the explanations for the country-level variations in unregistered employment,

1 Countries included in the sample Albania, Armenia, Azerbaijan, Estonia, Belarus, Bosnia and Herzegovina, Bulgaria, Croatia, Czech Republic, France, Georgia, Germany, Great Britain, Hungary, Italy, Kazakhstan, Kosovo, Kyrgyzstan, Latvia, Lithuania, Macedonia, Moldova, Mongolia, Montenegro, Poland, Romania, Russia, Serbia, Slovakia, Slovenia, Sweden, Tajikistan, Turkey, Ukraine, and Uzbekistan. including the influence of tax morale (as a proxy indicator of the degree of institutional asymmetry), which is becoming a very popular strand in recent research (Krasniqi and Desai 2016; Williams and Krasniqi 2017, Williams and Martínez 2014, Williams and Horodnic 2017b).

\subsection{Variables}

To analyse the above hypotheses, the dependent variable is a dichotomous variable extracted from the LiTs II (2010) survey based on the following question: " Do you have a written contract or a labour book for this job?". For the purposes of multi-level logit estimation, the dependent variable takes values of 1 when the answer is No, and 0 otherwise.

To analyse the hypotheses regarding the levels of unregistered employment across socio-demographic and socio-economic groups, the following individuallevel variables are analysed to test hypotheses $\mathrm{H} 1 \mathrm{a}-1 \mathrm{e}$ and $\mathrm{H} 2$ :

- Tax morale: a dummy variable with value of 1 if individual has answered - seriously wrong and wrong, and 0 otherwise from the following question: "how wrong if at all, do you consider the following behaviour: paying cash with no receipts to avoid paying VAT or other taxes: not wrong at all, a bit wrong, wrong, and seriously wrong"

- Gender: a dummy variable with value 1 for males and 0 for females.

- Age: a continuous variable for the age and its squared term.

- Marital status: a categorical variables for the marital status of the respondent with value 1 , for singles, for those separated or divorced, widowed, and value 0 for reference base category for married individuals.

- Number of Children: it is a continuous variable for the number of children below in the household.

- Household ownership: a categorical variable for the home ownership status of the respondent, with value 1 for those who are paying the mortgage or rent a house, and zero for those who own outright a house as a reference base category.

- Education: a categorical variable for the educational level with value of 1 for primary and secondary education, and zero for university or postgraduate education as a reference base category.

To analyse hypotheses $\mathrm{H} 3-\mathrm{H} 5$, we examine the country-level variables deemed important in each 
explanation. To do this, we here use data from the World Development Indicators database from 2010 and Transparency International (2014). To evaluate the modernisation hypotheses $\mathrm{H} 3 \mathrm{a}, \mathrm{H} 3 \mathrm{~b}$ and $\mathrm{H} 3 \mathrm{c}$, the respective indicators used are as follows:

- GDP per capita in purchasing power standards (current international \$). For the purposes of testing for a nonlinear relationship with tax morale, we constructed GDP per capita squared.

- Strength of legal rights index. Strength of legal rights index measures the degree to which collateral and bankruptcy laws protect the rights of borrowers and lenders and thus facilitate lending. The index ranges from 0 to 12, with higher scores indicating that these laws are better designed.

- CPI (corruption perception index). Public sector corruption perceptions index, which scores countries on a scale from zero to 10 , with zero indicating high levels and 10 low levels of perceived public sector corruption.

To evaluate the contrary 'state over-interference' and 'state under-intervention' hypotheses $(\mathrm{H} 3$ and $\mathrm{H} 4$ ), meanwhile, the indicators used to measure the level of social redistribution, and state intervention and expenditure, are:

- Subsidies and other transfers (\% of expense). Subsidies, grants, and other social benefits include all unrequited, nonrepayable transfers on current account to private and public enterprises; grants to foreign governments, international organizations, and other government units; and social security, social assistance benefits, and employer social benefits in cash and in kind.

- Social contributions (\% of revenue). Social contributions include social security contributions by employees, employers, and self-employed individuals, and other contributions whose source cannot be determined. They also include actual or imputed contributions to social insurance schemes operated by governments.

- Health expenditure per capita as a percentage of GDP per capita

\section{MULTI-LEVEL MODELLING}

Given the hierarchical structure of the data, with individuals nested within countries, for the econometric analysis we use a series of multilevel models. As the dependent variable is a binary variable taking a value of 1 if the respondent declared that $s /$ he is working without contract, and 0 otherwise, we employ mixedeffects logistic regression (Snijders and Bosker 2011,
Hamilton 2012). The likelihood-ratio test that there is no cross-country variation in unregistered employment can be safely rejected in baseline model as well as in all other models. This means that the mixedeffects logistic regression should be used. In the first stage of the analysis, a baseline random model with no explanatory variables was estimated to test whether a multilevel approach was appropriate for this analysis. The analysis shows that 8-12 per cent of the variance in participation in unregistered employment was accounted for at the country level (see ICC in Table 2). Random intercepts in the output above exhibit significant variation, judged by a likelihood-ratio test versus an ordinary logistic regression $(p=0.000)$, or by the standard deviation of random intercepts $(0.668)$ being much more than its standard error (0.082) (baseline Model 0). The Model 1 includes socio-demographic variables, while in Model 2 to Model 9 in sequence order country level indictors have been introduced.

Altogether, the seven models introducing these contextual variables (M2-5) improve significantly the explanatory power of models. Yet, the interclass correlation has only lowered to 8.2 (model 6) per cent from the initial 11.9 per cent of the baseline (MO model). The ICC still indicates that 8.2 per cent of the variation in participation in unregistered employment due to country level differences across the countries in our sample remains unexplained. The country level characteristics we consider to test our hypotheses only account for 2 per cent of the country level variation in unregistered employment. Cleary, there may be other country level factors that we do not consider here that may explain the differences. The final logit intercept model including both individual level explanatory variables and country-level explanatory variables takes the following form (see Steele 2009; Williams and Horodnic, 2017a):

$$
\log \left(\frac{\pi_{i j}}{1-\pi_{i j}}\right)=\beta_{0}+\beta_{1} X_{i j}+\beta_{2} X_{j}+u_{j}
$$

where, $\beta_{0}$ is the overall intercept, $\beta_{1}$ is the cluster specific effect, $\beta_{2}$ is the contextual effect, $X_{i j}$ is the vector containing individual level explanatory variables, $X_{j}$ is the vector containing country level explanatory variables and $u_{j}$ is the group (random) effect.

\section{RESULTS}

To evaluate firstly, whether the association between tax morale and participation in unregistered employment is significant when other characteristics are taken into account and held constant $(\mathrm{H} 1)$, 
Table 1: Multilevel Mixed-Effects Logistic Regression of Participation in Unregistered Employment

\begin{tabular}{|c|c|c|c|c|c|c|c|c|}
\hline VARIABLES & M0 & M1 & M2 & M3 & M4 & M5 & M6 & M7 \\
\hline Tax morale & & $\begin{array}{c}-0.162^{* * *} \\
(0.0368)\end{array}$ & $\begin{array}{c}-0.162^{* * *} \\
(0.0368)\end{array}$ & $\begin{array}{c}-0.162^{* * *} \\
(0.0368)\end{array}$ & $\begin{array}{c}-0.163^{* * *} \\
(0.0368)\end{array}$ & $\begin{array}{c}-0.166^{* * *} \\
(0.0410)\end{array}$ & $\begin{array}{c}-0.217^{* * *} \\
(0.0438)\end{array}$ & $\begin{array}{c}-0.146^{* * *} \\
(0.0372)\end{array}$ \\
\hline Gender (male) & & $\begin{array}{l}0.660^{* * *} \\
(0.0341)\end{array}$ & $\begin{array}{l}0.660^{* * *} \\
(0.0341)\end{array}$ & $\begin{array}{l}0.660^{* * *} \\
(0.0341)\end{array}$ & $\begin{array}{l}0.660^{* * *} \\
(0.0341)\end{array}$ & $\begin{array}{l}0.575^{* * *} \\
(0.0387)\end{array}$ & $\begin{array}{l}0.560^{* * *} \\
(0.0414)\end{array}$ & $\begin{array}{l}0.647^{* * *} \\
(0.0346)\end{array}$ \\
\hline Age & & $\begin{array}{l}0.0950^{* * *} \\
(0.00724)\end{array}$ & $\begin{array}{l}0.0951^{* * *} \\
(0.00724)\end{array}$ & $\begin{array}{c}0.0950^{* * *} \\
(0.00724)\end{array}$ & $\begin{array}{l}0.0953^{* * *} \\
(0.00724)\end{array}$ & $\begin{array}{c}0.0786^{* * *} \\
(0.00798)\end{array}$ & $\begin{array}{c}0.0713^{* * *} \\
(0.00855)\end{array}$ & $\begin{array}{l}0.0964^{* * *} \\
(0.00734)\end{array}$ \\
\hline Age squared & & $\begin{array}{c}-0.00126^{* * * *} \\
(8.11 \mathrm{e}-05)\end{array}$ & $\begin{array}{c}-0.00126^{* * *} \\
(8.11 \mathrm{e}-05)\end{array}$ & $\begin{array}{c}-0.00126^{* * *} \\
(8.11 \mathrm{e}-05)\end{array}$ & $\begin{array}{c}-0.00126^{* * *} \\
(8.11 \mathrm{e}-05)\end{array}$ & $\begin{array}{c}-0.00108^{* * *} \\
(8.80 \mathrm{e}-05)\end{array}$ & $\begin{array}{c}-0.00100^{* * * *} \\
(9.42 \mathrm{e}-05)\end{array}$ & $\begin{array}{c}-0.00128^{* * * *} \\
(8.21 \mathrm{e}-05)\end{array}$ \\
\hline \multicolumn{9}{|l|}{ Marital status (RC: Married) } \\
\hline Single & & $\begin{array}{c}0.0674 \\
(0.0485)\end{array}$ & $\begin{array}{c}0.0695 \\
(0.0485)\end{array}$ & $\begin{array}{c}0.0670 \\
(0.0485)\end{array}$ & $\begin{array}{c}0.0702 \\
(0.0485)\end{array}$ & $\begin{array}{c}0.0707 \\
(0.0542)\end{array}$ & $\begin{array}{l}0.123^{* *} \\
(0.0568)\end{array}$ & $\begin{array}{c}0.0700 \\
(0.0493)\end{array}$ \\
\hline Divorced/separated & & $\begin{array}{c}0.109^{*} \\
(0.0613)\end{array}$ & $\begin{array}{c}0.110^{*} \\
(0.0613)\end{array}$ & $\begin{array}{c}0.109^{*} \\
(0.0613)\end{array}$ & $\begin{array}{c}0.111^{*} \\
(0.0613)\end{array}$ & $\begin{array}{c}0.127^{*} \\
(0.0662)\end{array}$ & $\begin{array}{l}0.183^{* * *} \\
(0.0691)\end{array}$ & $\begin{array}{c}0.111^{*} \\
(0.0614)\end{array}$ \\
\hline Widowed & & $\begin{array}{c}-0.340^{* * *} \\
(0.0855)\end{array}$ & $\begin{array}{c}-0.341^{* * *} \\
(0.0855)\end{array}$ & $\begin{array}{c}-0.340^{* * *} \\
(0.0855)\end{array}$ & $\begin{array}{c}-0.341^{* * *} \\
(0.0855)\end{array}$ & $\begin{array}{c}-0.435^{* * *} \\
(0.0925)\end{array}$ & $\begin{array}{c}-0.449^{* * *} \\
(0.103)\end{array}$ & $\begin{array}{c}-0.339^{* * *} \\
(0.0856)\end{array}$ \\
\hline No of children & & $\begin{array}{l}-0.0195 \\
(0.0178)\end{array}$ & $\begin{array}{l}-0.0198 \\
(0.0178)\end{array}$ & $\begin{array}{l}-0.0196 \\
(0.0178)\end{array}$ & $\begin{array}{l}-0.0203 \\
(0.0178)\end{array}$ & $\begin{array}{c}-0.0716^{* * *} \\
(0.0219)\end{array}$ & $\begin{array}{c}-0.0744^{* * *} \\
(0.0243)\end{array}$ & $\begin{array}{l}-0.0161 \\
(0.0182)\end{array}$ \\
\hline \multicolumn{9}{|l|}{ Home ownership (RC owner) } \\
\hline Rented & & $\begin{array}{l}0.00790 \\
(0.0543)\end{array}$ & $\begin{array}{c}0.0138 \\
(0.0543)\end{array}$ & $\begin{array}{l}0.00872 \\
(0.0543)\end{array}$ & $\begin{array}{c}0.0152 \\
(0.0544)\end{array}$ & $\begin{array}{c}-0.0101 \\
(0.0584)\end{array}$ & $\begin{array}{c}-0.0245 \\
(0.0607)\end{array}$ & $\begin{array}{l}0.00775 \\
(0.0547)\end{array}$ \\
\hline Paying mortgage & & $\begin{array}{l}0.00481 \\
(0.0724)\end{array}$ & $\begin{array}{c}0.0146 \\
(0.0726)\end{array}$ & $\begin{array}{l}0.00564 \\
(0.0724)\end{array}$ & $\begin{array}{c}0.0138 \\
(0.0727)\end{array}$ & $\begin{array}{c}0.0158 \\
(0.0753)\end{array}$ & $\begin{array}{c}0.0292 \\
(0.0763)\end{array}$ & $\begin{array}{l}0.00141 \\
(0.0732)\end{array}$ \\
\hline \multicolumn{9}{|l|}{ Education (primary RC) } \\
\hline Secondary & & $\begin{array}{l}0.189^{* * *} \\
(0.0622)\end{array}$ & $\begin{array}{l}0.188^{* * *} \\
(0.0622)\end{array}$ & $\begin{array}{l}0.189^{* * *} \\
(0.0622)\end{array}$ & $\begin{array}{l}0.187^{* * *} \\
(0.0621)\end{array}$ & $\begin{array}{l}0.148^{* *} \\
(0.0703)\end{array}$ & $\begin{array}{c}0.115 \\
(0.0714)\end{array}$ & $\begin{array}{l}0.164^{* *} \\
(0.0640)\end{array}$ \\
\hline University & & $\begin{array}{l}-0.170^{* *} \\
(0.0728)\end{array}$ & $\begin{array}{l}-0.171^{* *} \\
(0.0728)\end{array}$ & $\begin{array}{l}-0.170^{* *} \\
(0.0728)\end{array}$ & $\begin{array}{l}-0.174^{* *} \\
(0.0727)\end{array}$ & $\begin{array}{c}-0.116 \\
(0.0810)\end{array}$ & $\begin{array}{l}-0.0205 \\
(0.0829)\end{array}$ & $\begin{array}{c}-0.194^{* * *} \\
(0.0742)\end{array}$ \\
\hline \multicolumn{9}{|l|}{ Country-level indicators } \\
\hline Corruption Perception Index & & & $\begin{array}{l}-0.114^{*} \\
(0.0619)\end{array}$ & & & & & \\
\hline Strength of legal rights index & & & & $\begin{array}{c}0.000135 \\
(0.000103)\end{array}$ & & & & \\
\hline GDP per capita & & & & & $\begin{array}{c}-9.04 \mathrm{e}-05^{* * *} \\
(2.94 \mathrm{e}-05)\end{array}$ & & & \\
\hline GDP per capita squared & & & & & $\begin{array}{c}1.67 \mathrm{e}-09^{* * *} \\
(6.46 \mathrm{e}-10)\end{array}$ & & & \\
\hline $\begin{array}{l}\text { Subsidies and other transfers (\% } \\
\text { of revenue) }\end{array}$ & & & & & & $\begin{array}{c}-0.0244^{* *} \\
(0.0110)\end{array}$ & & \\
\hline $\begin{array}{l}\text { Social contributions (\% of } \\
\text { revenue) }\end{array}$ & & & & & & & $\begin{array}{l}-0.0192^{*} \\
(0.00995)\end{array}$ & \\
\hline $\begin{array}{l}\text { Health expenditure, total (\% of } \\
\text { GDP) }\end{array}$ & & & & & & & & $\begin{array}{l}-0.000201^{* *} \\
(9.93 e-05)\end{array}$ \\
\hline Constant & $\begin{array}{c}-2.139 * * * \\
(0.115)\end{array}$ & $\begin{array}{c}-3.862^{* * *} \\
(0.203)\end{array}$ & $\begin{array}{c}-3.402^{* * *} \\
(0.319)\end{array}$ & $\begin{array}{c}-3.876^{* * *} \\
(0.203)\end{array}$ & $\begin{array}{c}-3.270^{* * * *} \\
(0.262)\end{array}$ & $\begin{array}{c}-2.072^{* * *} \\
(0.670)\end{array}$ & $\begin{array}{c}-2.821^{* * *} \\
(0.386)\end{array}$ & $\begin{array}{c}-3.602^{* * * *} \\
(0.240)\end{array}$ \\
\hline Observations & 38,864 & 36,263 & 36,263 & 36,263 & 36,263 & 30,049 & 28,276 & 35,198 \\
\hline Number of groups & 35 & 35 & 35 & 35 & 35 & 29 & 27 & 34 \\
\hline $\begin{array}{l}\text { Identity: country (Variance } \\
\text { constant) }\end{array}$ & 0.668 & .673 & .642 & .668 & .583 & .656 & .542 & .642 \\
\hline ICC & 0.119 & .121 & .111 & .119 & .093 & .115 & .082 & .111 \\
\hline LR Test & $1601^{* * *}$ & $1426^{* * *}$ & $1305^{* * *}$ & $1402^{* * *}$ & $1060^{* * *}$ & $1089^{* * *}$ & $583^{* * *}$ & $1210^{* * *}$ \\
\hline
\end{tabular}


secondly, whether various marginalised groups are more likely to engage in unregistered employment $(\mathrm{H} 2)$, and third and finally, the validity of the contrasting explanations for the cross-national variations in the prevalence of unregistered employment (H3-5), we here report the results of a multilevel logistic regression model, which utilises the hierarchical nature of the data (individuals within countries).

Examining whether there is a significant association between tax morale and participation in unregistered employment, this is found to be the case across all models (confirming $\mathrm{H} 1$ ). This reinforces previous work on this subject with regard to the wider informal economy (Williams and Franic 2015; Williams and Horodnic, 2015a,b,c, 2017; Williams et al. 2015) which has used tax morale as a proxy for the degree of institutional asymmetry. It displays that the greater the degree of institutional asymmetry, the greater is the prevalence of unregistered employment.

To evaluate the marginalisation thesis that unregistered employment is concentrated among populations marginalised from the formal labour market and social protection we introduce series of econometric models. Model 1 in Table evaluates the relationship between various socio-demographic and socio-economic characteristics and the likelihood of participation in unregistered employment. This shows that everything else being equal, men are more likely to participate in unregistered employment than women (refuting hypothesis 2a). Instead, it reveals how the exclusion of women from the formal labour market is further compounded when examining unregistered employment. It also reveals, similar to previous studies (European Commission 2014; Williams and Horodnic 2016) that younger age groups seem to have higher levels of participation in unregistered employment due to their greater exclusion form the formal labour market (confirming hypothesis $2 \mathrm{~b}$ ). However, it also reveals an inverted $U$-shaped relationship between age and unregistered employment, suggesting that participation in unregistered employment increase with age up to certain level and then decreases as age increases. It is also the case that divorced tend to have higher probability of engaging in unregistered employment compared with the reference group of married people (confirming $\mathrm{H} 2 \mathrm{c}$ ), while the widowed have less likelihood of participating in informal work. There is no relationship, however, between home ownership and those paying a mortgage and renting house, and participation in unregistered employment (refuting $\mathrm{H} 2 \mathrm{~d}$ ), although educational level is important. Individuals with secondary education are more to engage in unregistered employment and those with university education less likely, to engage in unregistered employment (confirming $\mathrm{H} 2 \mathrm{e}$ ).

To test H3-5 regarding the explanations for the cross-national variations in the prevalence of unregistered employment, and given that these country-level variables are strongly correlated (see Table A1 in the Appendix), sequential models are applied to provide alternative perspectives on the cross-national variations in the prevalence of unregistered employment.

Starting with the modernisation thesis, model 2 reveals that for the index of perceived public sector corruption, coded in a way where higher values mean lower levels of perceived public sector corruption, the lower is the perception of public sector corruption, the lower is the prevalence of unregistered employment (confirming $\mathrm{H} 3 \mathrm{~b}$ ). However, model 3 identifies no significant association between the strength of legal rights and the prevalence of unregistered employment (refuting $\mathrm{H} 3 \mathrm{c}$ ). In model 4, meanwhile, a significant U-shaped relationship is identified between unregistered employment and GDP per capita. That is, the higher the level of economic development as measured by GDP per capita is, the lower is the prevalence of unregistered employment, but this effect holds only after GDP per capita has reached some minimum level (confirming $\mathrm{H} 3 \mathrm{a}$ ), thus supporting the modernisation thesis.

Turning to the state over-interference versus the state under-intervention theses, a positive and statistically significant relationship is found for the two measures of social redistribution, namely subsidies and other transfers in model 5 , and social contribution expenditure in model 6 , as well as for one measure on the expenditure side of government, namely health expenditure in model 7 . The greater the state intervention and the greater the state expenditure on social redistribution, the lower is the prevalence of unregistered employment, thus supporting the state under-intervention thesis that unregistered employment will be less prevalent in economies with higher levels of state expenditure (confirming $\mathrm{H} 5$ ) and negating the state over-interference thesis that unregistered employment will be more prevalent in economies with higher levels of state expenditure (refuting $\mathrm{H} 4$ ).

\section{DISCUSSION AND CONCLUSIONS}

To evaluate whether unregistered employment is more likely to be conducted by marginalised populations, this paper has revealed that that younger age groups, the divorced, and those with fewer years in education, are more likely to be unregistered employed. However, women and those not owning their own household are not more likely to do so. On a 
country-level, meanwhile, the prevalence of unregistered employment is strongly associated with tax morale; the greater the asymmetry between informal and formal institutions, the greater is the prevalence of unregistered employment. It is also higher when GDP per capita as well as social distribution and state intervention (subsidies and transfers, social contribution expenditure, health expenditure) are lower.

In terms of theoretical advances therefore, this paper makes three major contributions. Firstly, it reveals some support for the marginalisation thesis in relation to unregistered employment, although it reveals that care is required when identifying which marginal groups are more likely to engage in unregistered employment. Secondly, by revealing the strong association between tax morale and participation in unregistered employment, it confirms the usefulness of an institutional theory lens. The greater the degree of asymmetry between the codified laws and regulations of formal institutions and the norms, values and beliefs of citizens that constitute the informal institutions, the greater is the prevalence of unregistered employment. Thirdly, and importantly for advancing understanding of unregistered employment from an institutional theory viewpoint, the finding of this multi-level analysis (individuals within countries) is that the propensity to engage in unregistered employment is higher when the level of economic development is lower (confirming modernisation theory) and when the levels of social distribution and state intervention (subsidies and transfers, social contribution expenditure, health expenditure) are lower (confirming state under-intervention theory and refuting state over-interference theory).

In terms of policy implications therefore, the finding is that reducing the prevalence of unregistered employment will require a new emphasis on the reduction of institutional asymmetry, which will require changes in both informal and formal institutions. To determine the changes in formal institutions required, this paper has revealed that there needs to be a focus upon not only awareness raising to change attitudes norms and beliefs but also the formal institutional failings and imperfections that lead to this asymmetry, namely by increasing the level of GDP per capita and importantly, increasing spending on social distribution and state intervention (subsidies and transfers, social contribution expenditure, health expenditure).

There are, however, limitations to this study and what is known. It is not currently known how the working conditions of those engaged in unregistered employment differ to their equivalents in registered employment, nor their motives for engaging in such employment. Until this is evaluated, the evidence-base on the implications of unregistered employment will remain unknown. Moreover, only a limited range of country-level structural conditions associated with unregistered employment have been evaluated, albeit selected based on existing theoretical positions. Future research might evaluate a wider range of country-level structural conditions, albeit from a similar theoretically-driven perspective from the emergent understanding of this form of work. It would also be useful to know whether similar findings are identified in other global regions as has been identified across these 35 Eurasian countries.

In sum, this paper has revealed the individual- and country-level variations in unregistered employment, revealing that unregistered employment is concentrated among marginal groups and that it is more prevalent in countries where the degree of asymmetry between formal and informal institutions is greater, and where there are lower levels of GDP per capita and lower levels of social distribution and state intervention. If this stimulates further research on unregistered employment both to develop a more in-depth understanding and to test whether similar findings are identified in other global regions, then it will have fulfilled one of its intentions. If this then leads to a reconsideration of how unregistered employment is tackled, and to greater emphasis being put on tackling the formal institutional imperfections and failings that lead to this institutional asymmetry, and thus higher levels of unregistered employment, then it will have fulfilled its wider intention.

\section{REFERENCES}

Andrews, D., Caldera Sanchez, A. and Johansson, A. 2011. Towards a better understanding of the informal economy. Working Paper No. 873. Paris: OECD Economics Department.

Baumol, W.J. and Blinder, A. 2008. Macroeconomics: principles and policy. Cincinnati $\mathrm{OH}$ : South-Western Publishing.

Brill, L. 2011. Women's participation in the informal economy: what can we learn from Oxfam's work?. Manchester: Oxfam.

Castells, M. and Portes. A. 1989. World underneath: the origins, dynamics and effects of the informal economy. In The informal economy: studies in advanced and less developing countries, edited by A. Portes, M. Castells and L. Benton, 11-40. Baltimore: John Hopkins University Press.

Davis, M. 2006. Planet of Slums, London: Verso.

De Soto, H. 2001. The Mystery of capital: why capitalism triumphs in the west and fails everywhere else. London: Black Swan. 
EBRD 2011. Life in transition after the crises. Research report. London: European Bank for Reconstruction and Development.

European Commission 2014. Employment and social developments in europe 2013. Brussels: European Commission DG for Employment, Social Affairs and Inclusion.

European Commission 2016. Decision (EU) 2016/344 of the European Parliament and of the council of 9 march 2016 on establishing a european platform to enhance cooperation in tackling undeclared work.

Gallin, D. 2001. Propositions on trade unions and informal employment in times of globalisation. Antipode 33 (3): 531-549.

Hamilton, L. 2012. Statistics with STATA: Version 12. Boston, MA: Cengage Learning.

Hashi, I. and Krasniqi, B. A. 2011. Entrepreneurship and SME growth: evidence from advanced and laggard transition economies. International Journal of Entrepreneurial Behavior \& Research 17 (5): 456-487.

Hazans, M. 2011. Informal workers across Europe: evidence from 30 countries. Policy Research Working Paper 5912. Washington, DC: World Bank.

Helmke, G. and Levitsky, S. 2004. Informal institutions and comparative politics: A research agenda. Perspectives on Politics 2 (4): 725-740.

ILO 2011. Statistical update on employment in the informal economy. Geneva, ILO: Department of Statistics.

2013. Women and men in the informal economy: statistical picture, available at: http://laborsta.ilo.org/informal_economy_E.html (last accessed 18 August 2016).

2015. Transitioning from the informal to the formal economy. Geneva: ILO.

Jütting, J. and J. Laiglesia 2009. Employment, poverty reduction and development: what's new?. In Is informal normal? towards more and better jobs in developing countries, edited by J. Jütting and J. Laiglesia, 17-26. Paris, OECD.

Khan, E. A. and Khan, E. A. 2017. An investigation of marketing capabilities of informal microenterprises: a study of street food vending in Thailand. International Journal of Sociology and Social Policy 37 (3/4):186-202.

Kistruck, G. M., Webb, J. W., Sutter, C. J., and Bailey, A. V. 2015. The double-edged sword of legitimacy in base-of-thepyramid markets. Journal of Business Venturing 30(3): 436-451.

Krasniqi, B. A. 2011. Entrepreneurship and small business development in Kosova. New Work: Nova Science Publishers.

2014. Characteristics of self-employment: a refuge from unemployment or road to entrepreneurship. Small Enterprise Research 21 (1): 33-53.

Krasniqi, B. A., and Mustafa, M. 2016. Small firm growth in a post-conflictenvironment:therole ofhumancapital, institutional quality, and managerial capacities. International
Entrepreneurship and Management Journal 12 (4): 1165-1207.

Krasniqi, B. and Desai, S. 2016. Institutional drivers of highgrowth firms: country-level evidence from 26 transition economies. Small Business Economics 47 (4): 1075-1094.

Krasniqi, B.A. 2007. Barriers to entrepreneurship and SME growth in transition: the case of Kosova. Journal of Developmental Entrepreneurship 12 (1): 71-94.

Lajqi, S., and Krasniqi, B. A. 2017. Entrepreneurial growth aspirations in challenging environment: the role of institutional quality, human and social capital. Strategic Change 26(4): 385-401.

Lemieux, T., Fortin, B., and Frechette, P. 1994. The effect of taxes on labor supply in the underground economy. The American Economic Review 231-254.

Leonard, M. 1994. Informal economic activity in Belfast. Avebury: Aldershot.

Lewis, A. 1959. The theory of economic growth. London: Allen and Unwin.

London, T. and Hart, S. L. 2004. Reinventing strategies for emerging markets: beyond the transnational model. Journal of International Business Studies 35 (5): 350-370.

Mclnnis-Dittrich, K. 1995. Women of the shadows: Appalachian womenss participation in the informal economy. Affilia 10(4): 398-412.

North, D. C. 1990. Institutions, institutional change and economic performance. Cambridge: University Press,

Nwabuzor, A. 2005. Corruption and development: new initiatives in economic openness and strengthened rule of law. Journal of Business Ethics 59 (1): 121-138.

Packard, T. 2007. Do workers in Chile choose informal employment? a dynamic analysis of sector choice. Washington DC: World Bank Latin American and the Caribbean Region Social Projection Unit.

Schneider, F. and Williams, C.C. 2013. The shadow economy. London: Institute of Economic Affairs.

Slack, T., Slack, T., Cope, M. R., Cope, M. R., Jensen, L., Jensen, L., and Tickamyer, A. R. 2017. Social embeddedness, formal labor supply, and participation in informal work. International Journal of Sociology and Social Policy 37 (3/4): 248-264.

Slavnic, Z. 2010. Political economy of informalization. European Societies 12 (1): 3-23.

Snijders, T. A. and Bosker, R. J. 2011. Multilevel analysis: an introduction to basic and advanced multilevel modeling. London: SAGE.

Stănculescu, M. 2005. Working conditions in the informal sector. SEER: Journal for Labour and Social Affairs in Eastern Europe 8 (3): 79-93.

Steele, F. 2009. Regression models for binary responses concepts. Bristol, UK: Center for Multilevel Modelling, University of Bristol. 
Taiwo, O. 2013. Employment choice and mobility in multisector labour markets: theoretical model and evidence from Ghana. International Labour Review 152 (3-4): 469-492.

Tonoyan V, Strohmeyer R, and Habib, M. 2010. Corruption and entrepreneurship: how formal and informal institutions shape small firm behavior in transition and mature market economies. Entrepreneurship Theory and Practice 27(6): 803-832.

Webb, J. W., Tihanyi, L., Ireland, R. D., and Sirmon, D. G. 2009. You say illegal, I say legitimate: entrepreneurship in the informal economy. Academy of Management Review 34 (3): 492-510.

Williams, C. 2012. Cross-national variations in the under-reporting of wages in south-east Europe: a result of overregulation or under-regulation?. South East European Journal of Economics and Business 7 (1): 53-61.

Williams, C. and Krasniqi, B. 2017. Evaluating the individual-and country-level variations in tax morale: evidence from 35 Eurasian countries. Journal of Economic Studies 44 (5): 816-832.

Williams, C. C. 2001. Tackling the participation of the unemployed in paid informal work: a critical evaluation of the deterrence approach. Environment and Planning C: Government and Policy 19 (5): 729-749. 2013. Evaluating cross-national variations in the extent and nature of informal employment in the European Union. Industrial Relations Journal 44(5-6): 479-494.

2014. Confronting the shadow economy: evaluating tax compliance and behaviour policies. Edward Elgar Publishing. 2017. Developing a holistic approach for tackling undeclared work. Brussels: European Commission.

Williams, C. C. and Franic, J. 2015. Tackling the propensity towards undeclared work: some policy lessons from Croatia. South East European Journal of Economics and Business 10(1), 18-31.

Williams, C. C. and Horodnic, I. 2015a. Marginalisation and participation in the informal economy in Central and Eastern European nations. Post-Communist Economies 27 (2), 153-169.

Williams, C. C., and Horodnic, I. A. 2015b. Self-employment, the informal economy and the marginalisation thesis: some evidence from the European Union. International Journal of Entrepreneurial Behaviour and Research 21 (2): 224-242.

2017a. Evaluating the relationship between social exclusion and participation in the informal sector in the European Union. International Journal of Manpower 38 (3): 489-503.

Williams, C. C. and Martínez, Á. 2014. Explaining cross-national variations in tax morality in the European Union: an exploratory analysis. Studies of Transition States and Societies 6 (1): 5-18.

Williams, C. C. and Schneider, F. 2016. Measuring the global shadow economy: the prevalence of informal work and labour. Edward Elgar Publishing.

2015c. Rethinking the marginalisation thesis: an evaluation of the sociospatial variations in undeclared work in the European Union. Employee Relations 37 (1): 48-65.

2017b. Evaluating

the illegal employer practice of under-reporting employees' salaries. British Journal of Industrial Relations 55 (1): 83-111.

Williams, C. C., and Windebank, J. 1998. Informal employment in the advanced economies: implications for work and welfare. London: Routledge.

Williams, C. C., Franic, J. and Dzhekova, R. 2015. Explaining the undeclared economy in Bulgaria: an institutional asymmetry perspective. South East European Journal of Economics and Business 9 (2): 33-45.

Williams, C. C., Williams, C. C., Kayaoglu, A. and Kayaoglu, A. 2017. Evaluating the prevalence of employees without written terms of employment in the European Union. Employee Relations 39 (4): 487-502.

Williams, N., and Vorley, T. 2015. Institutional asymmetry: how formal and informal institutions affect entrepreneurship in Bulgaria. International Small Business Journal 33 (8): 840-861.

Williams, N., Vorley, T. and Williams, C. 2017. Entrepreneurship and institutions: the causes and consequences of institutional asymmetry. Rowman and Littlefield.

Windebank, J., Windebank, J., Horodnic, I. A., and Horodnic, I. A. 2017. Explaining participation in undeclared work in France: lessons for policy evaluation. International Journal of Sociology and Social Policy 37 (3/4): 203-217. 
Table A: Correlations amongst the Country Level Variables

\begin{tabular}{|c|c|c|c|c|c|c|c|c|}
\hline & Variables & $\begin{array}{l}\text { Corruption } \\
\text { Perception } \\
\text { Index }\end{array}$ & $\begin{array}{c}\text { Strength of } \\
\text { the legal rights } \\
\text { index }\end{array}$ & $\begin{array}{c}\text { GDP } \\
\text { per capita }\end{array}$ & $\begin{array}{l}\text { GDP per capita } \\
\text { squared }\end{array}$ & $\begin{array}{l}\text { Subsidies and } \\
\text { other transfers } \\
\text { (\% of revenue) }\end{array}$ & $\begin{array}{l}\text { Social contri- } \\
\text { butions ( } \% \text { of } \\
\text { revenue) }\end{array}$ & $\begin{array}{c}\text { Health } \\
\text { expenditure, } \\
\text { total (\% of } \\
\text { GDP) }\end{array}$ \\
\hline 1 & $\begin{array}{l}\text { Corruption Perception } \\
\text { Index }\end{array}$ & 1.000 & & & & & & \\
\hline 2 & $\begin{array}{l}\text { Strength of the legal } \\
\text { rights index }\end{array}$ & $0.268^{* * *}$ & 1.000 & & & & & \\
\hline 3 & GDP per capita & $0.837^{* * *}$ & $-0.013^{*}$ & 1.000 & & & & \\
\hline 4 & GDP per capita squared & $0.788^{* * *}$ & -0.002 & $0.966^{* * *}$ & 1.000 & & & \\
\hline 5 & $\begin{array}{l}\text { Subsidies and other } \\
\text { transfers (\% of revenue) }\end{array}$ & $0.190^{* * *}$ & $0.090^{* * *}$ & $0.213^{* * *}$ & $0.142^{* * *}$ & 1.000 & & \\
\hline 6 & $\begin{array}{l}\text { Social contributions (\% } \\
\text { of revenue) }\end{array}$ & $0.290 * * *$ & $-0.186^{* * *}$ & $0.240^{* * *}$ & $0.089^{* * *}$ & $0.616^{* * *}$ & 1.000 & \\
\hline 7 & $\begin{array}{l}\text { Health expenditure, } \\
\text { total (\% of GDP) }\end{array}$ & $0.816^{* * *}$ & -0.004 & $0.969^{* * *}$ & $0.908^{* * *}$ & $0.260 * * *$ & $0.360^{* * *}$ & 1.000 \\
\hline
\end{tabular}

${ }^{*} p<0.05,{ }^{* *} p<0.01,{ }^{* * *} p<0.00$ 